RESEARCH ARTICLE

\title{
Studying the impact factors of climate change on agricultural land use in Phong Dien district, Thua Thien Hue province
}

\author{
Nghiên cứu các yếu tố tác động của biến đổi khí hậu đến sử dụng đất nông nghiệp trên địa \\ bàn huyện Phong Điền, tỉnh Thừa Thiên Huế
}

NGUYEN, Van Binh; HO, Nhat Linh*

Faculty of Land Resources and Agricultural Environment, Hue University of Agriculture and Forestry, Hue University, 102 Phung Hung, Hue City, Vietnam

\begin{abstract}
Many factors influence agricultural land, in particular, climate change show the most significant and serious effect on agricultural land in Phong Dien district. This study applied Binary Logistic analysis, using the SPSS software, on data collected through state agencies, fieldwork and interviews. The study has identified the impact of climate change on agricultural land by several factors; the most significant influence is derived from temperature and other extreme weather factors. In addition, the elements of rainfall, wind, and cold air also have a substantial impact on agricultural land causing serious consequences such as damage, loss of construction quality, overload of water supply and drainage systems, landslides, damage to infrastructure systems, etc. Some adaptive solutions to counteract the effects of climate change on agricultural land include changing crop structure, upgrading facilities, raising awareness of officials, and people about climate change.
\end{abstract}

Công tác sử dụng đất nông nghiệp chịu ảnh hưởng từ rất nhiều yếu tố. Trong đó, yếu tố tác động của biến đổi khí hậu gây ảnh hưởng lớn và nghiêm trọng nhất đối với việc sử dụng đất nông nghiệp nói chung và trên địa bàn huyện Phong Điền nói riêng. Nghiên cứu đã sử dụng phân tích Binary Logistic trên phần mềm SPSS từ các số liệu thu thập được qua các cơ quan nhà nước, thực địa, phỏng vấn. Từ đó, nghiên cứu đã xác định được tác động của biến đổi khí hậu đến sử dụng đất nông nghiệp thông qua các yếu tố: Gây ảnh hưởng lớn nhất là yếu tố nhiệt độ và yếu tố cực đoan khác; ngoài ra, các yếu tố lượng mưa, chế độ gió và không khí lạnh cũng tác động không nhở vào việc sử dụng đất nông nghiệp. Các yếu tố này gây ra các hậu quả nghiêm trọng như làm hư hại, giảm chất lượng công trình, làm quá tải hệ thống cấp thoát nước, làm sạt lở, hư hại hệ thống cơ sở ha tầng... Nghiên cứu đã đề xuất được một số giải pháp thích ứng của biến đổi khí hậu đến việc sử dụng đất nông nghiệp như thay đổi cơ cấu cây trồng, nâng cấp cơ sở vật chất, nâng cao nhận thức của cán bộ và người dân về biến đổi khíhậu.

Keywords: Climate change, agricultural land use, Phong Dien district

\section{Introduction}

Nowadays environmental hazards and related challenges are no longer limited to individual countries or regions but are global. Vietnam is one of the five countries being most affected by climate change (Tho Dang, 2013). Intense and abnormal climate variations (climate change) is an existing risk for the sustainable development of every country. Global warming and rising water levels, along with extreme weather events (storms, floods, droughts, etc.) have significantly affected land use, especially the agricultural sector. Over the past 50 years, the average temperature has increased by $0.5^{\circ} \mathrm{C}$ and the sea level has risen about $20 \mathrm{~cm}$; the consequences have become more and more severe. According to climate change scenarios, by the end of the 21st century, the annual average temperature in Vietnam will increase by $2-3^{\circ} \mathrm{C}$. Estimations point out that the total annual rainfall and the precipitation volume during the wet season will increase; in an opposite way, precipitation during the dry season will decrease. Further estimates indicate that the sea level may rise from about $75 \mathrm{~cm}$ to $1 \mathrm{~m}$ compared to the average in the period 1980 - 1990. If the action programs, such as Kyoto Protocol in 1997, are not implemented to reduce greenhouse gas emissions, by 2035, the surface temperature of the planet is expected to increase up to $2^{\circ} \mathrm{C}$. It is predicted that in the future there is a $50 \%$ chance that the temperature will increase by $5^{\circ} \mathrm{C}$. In the case of Vietnam, if the sea level rises by $1 \mathrm{~m}$, approximately $40 \%$ of the Mekong Delta, $11 \%$ of the Red River Delta and $3 \%$ of coastal provinces will be inundated ( $\mathrm{Vi}$ etnam Financial Review, 2019). 
Phong Dien is a northern gateway district of the Thua Thien Hue province. Surrounded by the Bo River and the O Lau River, Phong Dien is a land with a long history and cultural traditions. Phong Dien district has a very diverse topography with 3 main types: mountainous areas, hilly areas and Deltas (lagoons and coastal areas); each area holds abundant mineral natural resources. With such geographical and natural conditions, the Phong Dien district has many advantages for agricultural development. However, its neighboring to the sea and to big rivers, makes this district potentially risky, especially under unpredictable climate change conditions.

In recent decades, people constantly suffer from extreme weather phenomena such as storms, floods, tropical low pressures, etc. The Phong Dien district has suffered many storms of vigorous intensity, which have destroyed many coastal ecosystems, strongly affecting the local agriculture and seafood industry (Communist party of Vietnam online newspaper, 2018).

In recent years, the prolonged heat, due to the effects of climate change, has caused pests to arise on a large scale and outbreaks of epidemics on cattle and poultry in many places. These negative effects make farmers to question about further investment in production. In addition to the aforementioned problematic, plant growth and development are also declining due to climate change factors. Due to the aforementioned problematic, the study of the impact factors of climate change on agricultural land use in Phong Dien district is very important.

\section{Data and methodologies}

\subsection{Data collection}

This study collected secondary data from reliable sources such as the Department of Natural Resources and Environment, the People's Committee of Phong Dien district and the People's Committee of the communes in the district.

For primary data, field surveys were conducted, consulting experts and officials in relevant fields. Through the survey process, four typical communes being heavily affected by climate change were identified in the study area: Phong My, Phong Thu, Dien Hai and Phong Hai. Based on the lectures of Nguyen Minh Hieu (2009), the sample size determined for each commune was derived from the collected data; according to the Slovin's Formula we estimate:

$$
\mathrm{n}=\frac{N}{1+N \cdot e^{2}}
$$

where $\mathrm{n}$ is the sample size (number of questionnaires); $\mathrm{N}$ is the total number of farming households in each commune and e is the standard error. The sample size of this research, with a value of $e=5 \%$, is displayed in Table 1 .

\section{Table 1. Sample size distribution in the study}

\begin{tabular}{|c|c|c|c|}
\hline Area & $\begin{array}{l}\text { Households } \\
(\mathrm{N})\end{array}$ & $\begin{array}{l}\text { Questionnaires } \\
\text { (n) }\end{array}$ & Reason for selection \\
\hline $\begin{array}{l}\text { Phong } \\
\text { My }\end{array}$ & 60 & 52 & $\begin{array}{l}\text { Area heavily affected by } \\
\text { drought }\end{array}$ \\
\hline $\begin{array}{l}\text { Phong } \\
\text { Thu }\end{array}$ & 69 & 59 & $\begin{array}{l}\text { Area influenced by in- } \\
\text { undation and drought }\end{array}$ \\
\hline Dien Hai & 104 & 82 & $\begin{array}{l}\text { Area affected by salt- } \\
\text { water intrusion }\end{array}$ \\
\hline $\begin{array}{l}\text { Phong } \\
\text { Hai }\end{array}$ & 35 & 32 & $\begin{array}{l}\text { Area is heavily affected } \\
\text { by storms, cold air }\end{array}$ \\
\hline Total & 268 & 225 & \\
\hline
\end{tabular}

\subsection{Data analysis method}

The study applied a binary logistic regression model utilizing the SPSS software to investigate the relevant factors of climate change in this region. A Binary logistic regression model is a regression model used to estimate the probability of an event to occur. This model has a binary variable with 2 values, 0 and 1 .

In this study, the secondary variable is the agricultural land use with values of 0 (meaning no influence) and 1 (having influence). The independent variables are temperature, rainfall, cold wind and air. Other extreme weather values are also evaluated as 0 or 1 . In this study, a group of authors have evaluated extreme weather factors such as droughts, storms, cyclones, etc. However, we separate the wind and cold air for a more detailed study. Before including the variables into the regression model, the variables need to be checked for multicollinearity.

Multicollinearity is a state in which the correlated independent variables exist in the model. Multiple collinearities either falsify or sign the regression coefficients in the regression equation, making the model's coefficients less meaningful. At the same time, multicollinearity provides to the model virtual or similar information, turning difficult to separate the influence of each independent variable on the dependent variable.

The easiest way to eliminate multiple collinearities is to remove the variable with the high collinearity sign from the model. To check the multicollinearity phenomenon, a Variance Inflation Factor (VIF) can be used to determine the sign of multiplicity. The formula calculates the VIF coefficient:

$$
V I F=\frac{1}{1-R_{K}^{2}}
$$

In which $\mathrm{R}_{\mathrm{K}}^{2}$ is the multiple correlation coefficient of the $\mathrm{k}_{\mathrm{th}}$ variable in the regression model. The larger the VIF coefficient, the higher the collinearity. According to Gujarati (2008), if the VIF of a variable exceeds 10, the variable is considered highly collinear and excluded from the model. 
The Binary Logistic regression has the form:

$$
\log _{e}\left[\frac{P_{i}}{1-P_{i}}\right]=B_{0}+B_{1} X_{1}+B_{2} X_{2}+B_{3} X_{3}+B_{4} X_{4}
$$

In which $\mathrm{P}_{\mathrm{i}}$ is the probability of land use being affected by the factors of climate change (the value 1 occurs in the binary variable); e 2.17; $B_{0}, B_{1}, B_{2}, B_{3}, B_{4}$ are the regression coefficients; $X_{1}, X_{2}, X_{3}, X_{4}$ are independent variables. A very powerful application of Binary Logistic regression is its predictability. From the regression equation, we have the following equation to calculate $\mathrm{P}_{\mathrm{i}}$ :

$$
\mathrm{Pi}=\mathrm{E}(\mathrm{Y}=1 / \mathrm{X})=\frac{e^{\left(\mathrm{B}_{0}+\mathrm{B}_{1} \mathrm{X}_{1}+\mathrm{B}_{2} \mathrm{X}_{2}+\mathrm{B}_{3} \mathrm{X}_{3}+\mathrm{B}_{4} \mathrm{X}_{4}\right)}}{1+e^{\left(\mathrm{B}_{0}+\mathrm{B}_{1} \mathrm{X}_{1}+\mathrm{B}_{2} \mathrm{X}_{2}+\mathrm{B}_{3} \mathrm{X}_{3}+\mathrm{B}_{4} \mathrm{X}_{4}\right)}}
$$

The previous equation predicts the occurrence of an event $i$ when the independent variables have specific values. Where $\mathrm{Pi}=\mathrm{E}(\mathrm{Y}=1 / \mathrm{X})=\mathrm{P}(\mathrm{Y}=1)$ is called the probability that the event will occur $(Y=1)$ when the independent variable $X$ has a specific value $X i]$.

Through the above regression equation, it is possible to determine which factors of climate change will have the strongest impact and which factors will have the least impact on agricultural land use through the regression coefficient $\mathrm{Bi}$.

From the results of the calculation of regression coefficients and the relationship between climatic factors, natural disasters and the change of land use, the land use change can be estimated. Therefore, changing grades of climatic factors and natural disasters is estimated with the formula presented by Hair et al, (1998):

$$
\mathrm{Y}=\frac{e^{B_{0}}+e^{B_{i}}}{e^{B_{0}}}
$$

In which $B_{0}$ is a constant $(-3,421)$ and $B_{i}$ is the regression coefficient of independent variables. In this formula, $Y$ shows the number of times in which the impact of agricultural land use depends on the change of climatic factors and natural disasters. It is then assumed that: when one climate/natural disaster factor changes one level and other factors do not change, the land use will change.

\section{Results and discussion}

\subsection{Build of the Binary Logistic regression}

\subsubsection{Setup input data}

The logistic regression equation shows the regression relationship between the dependent variable and the independent variable. The dependent variable is agricultural land use and the selected independent variables include: temperature, rainfall, changes in wind and cold air and other extreme weather conditions. Values of the variables were surveyed at 225 households in 4 communes in the Phong Dien district. Surveys' results are presented by individual variables.

\section{Temperature variable}

According to results displayed in Table 2, the temperature affecting agricultural land use accounts for $79.1 \%$ in the study area.

Table 2. Effect of temperature on agricultural land use

\begin{tabular}{lllll}
\multirow{2}{*}{ Criteria } & & \multicolumn{3}{l}{ Temperature } \\
\cline { 3 - 5 } & & No & Yes & Total \\
\hline \multirow{2}{*}{ Phong My } & Selection & 7 & 45 & 52 \\
& Rate (\%) & 3.11 & 20.00 & 23.11 \\
\multirow{2}{*}{ Phong Thu } & Selection & 4 & 55 & 59 \\
& Rate (\%) & 1.78 & 24.44 & 26.22 \\
\multirow{2}{*}{ Phong Hai } & Selection & 16 & 16 & 32 \\
& Rate (\%) & 7.11 & 7.11 & 14.22 \\
\multirow{2}{*}{ Dien Hai } & Selection & 20 & 62 & 82 \\
& Rate (\%) & 8.89 & 27.56 & 36.44 \\
\multirow{2}{*}{ Total } & Selection & 47 & 178 & 225 \\
& Rate (\%) & 20.89 & 79.11 & 100.00 \\
\hline
\end{tabular}

In recent years, temperatures are incrementing, affecting the local people's land use, mainly in coastal communes, lagoons and housing areas.

\section{Rainfall variable}

As it can be seen in Table 3, rainfall significantly affects agricultural land use in the Phong Dien district (accounting for nearly 64.4\%). The effect of rain is concentrated in the coastal and plain areas.

\section{Table 3. Effect of rainfall on agricultural land use}

\begin{tabular}{lllll}
\multirow{2}{*}{ Criteria } & & \multicolumn{2}{l}{ Rainfall } & \\
\cline { 3 - 5 } & & No & Yes & Total \\
\hline \multirow{2}{*}{ Phong My } & Selection & 34 & 18 & 52 \\
& Rate (\%) & 15.11 & 8.00 & 23.11 \\
\multirow{2}{*}{ Phong Thu } & Selection & 17 & 42 & 59 \\
& Rate (\%) & 7.56 & 18.67 & 26.22 \\
\multirow{2}{*}{ Phong Hai } & Selection & 9 & 23 & 32 \\
& Rate (\%) & 4.00 & 10.22 & 14.22 \\
\multirow{2}{*}{ Dien Hai } & Selection & 20 & 62 & 82 \\
& Rate (\%) & 8.89 & 27.56 & 36.44 \\
\multirow{2}{*}{ Total } & Selection & 80 & 145 & 225 \\
& Rate (\%) & 35.56 & 64.44 & 100.00 \\
\hline
\end{tabular}

Wind, cold air variable

This study has separated wind and cold air factors from extreme weather factors because extreme weather conditions usually promote other phenomena such as floods, storms, droughts, etc. Therefore, to make the research and the analysis easier, we consider the wind factor and cold air as a separate factor. Wind and cold air are a major factor affecting agricultural land use (67.6\%). This percentage is mainly concentrated in coastal areas, especially the Phong Hai commune, where the district is the most abundant in aquaculture and fishing (Table 4). 
Table 4. Effect of wind and cold air on agricultural land use

\begin{tabular}{lllll}
\multirow{2}{*}{ Criteria } & & \multicolumn{3}{l}{ Wind, cold air } \\
\cline { 3 - 5 } & & No & Yes & Total \\
\hline \multirow{2}{*}{ Phong My } & Selection & 15 & 37 & 52 \\
& Rate (\%) & 6.67 & 16.44 & 23.11 \\
\multirow{2}{*}{ Phong Thu } & Selection & 34 & 25 & 59 \\
& Rate (\%) & 15.11 & 11.11 & 26.22 \\
\multirow{2}{*}{ Phong Hai } & Selection & 1 & 31 & 32 \\
& Rate (\%) & 0.44 & 13.78 & 14.22 \\
\multirow{2}{*}{ Dien Hai } & Selection & 23 & 59 & 82 \\
& Rate (\%) & 10.22 & 26.22 & 36.44 \\
\multirow{2}{*}{ Total } & Selection & 73 & 152 & 225 \\
& Rate (\%) & 32.44 & 67.56 & 100.00 \\
\hline
\end{tabular}

Other extreme weather variables

Other extreme weather conditions affect almost all of the agricultural land in the Phong Dien district, accounting for a huge proportion (77.8\%). Other extreme weather conditions in this district are synthesized from common and frequent phenomena such as droughts, floods, storms, saltwater intrusion, landslides and cyclones. These events greatly affect the cultivated area and animal breeding in the whole district (Table 5).

\section{Set up the model's input database}

Dependent and independent variables are encoded as binary values of 0 and 1 , where a value of 1 means influenced and value 0 means unaffected. Particularly, the weather independent variable has many small variables (dummy variable), so it is synthesized and encoded into the same variable as other extreme weather variables (0 or 1).
Table 5. Effect of other extreme weather on agricultural land use

\begin{tabular}{lllll}
\multirow{2}{*}{ Criteria } & & \multicolumn{3}{l}{ Other extreme weather } \\
\cline { 3 - 5 } & & No & Yes & Total \\
\hline \multirow{2}{*}{ Phong My } & Selection & 8 & 44 & 52 \\
& Rate (\%) & 3.56 & 19.56 & 23.11 \\
\multirow{2}{*}{ Phong Thu } & Selection & 11 & 48 & 59 \\
& Rate (\%) & 4.89 & 21.33 & 26.22 \\
\multirow{2}{*}{ Phong Hai } & Selection & 10 & 22 & 32 \\
& Rate (\%) & 4.44 & 9.78 & 14.22 \\
\multirow{2}{*}{ Dien Hai } & Selection & 21 & 61 & 82 \\
& Rate (\%) & 9.33 & 27.11 & 36.44 \\
\multirow{2}{*}{ Total } & Selection & 50 & 175 & 225 \\
& Rate (\%) & 22.22 & 77.78 & 100.00 \\
\hline
\end{tabular}

\subsubsection{Calculation results}

The variables with coded values after sampling are included in the logistic regression model to calculate the relationship between climate change impacts and agricultural land use in the area.

Correlation between the factors of climate change impacts with agricultural land use in the study area

From the results displayed in Table 6, it is found that the coefficients (Sig. $<0.05$ ) are accepted as independent variables to being included in the regression model. On the other hand, the factors that affect climate change are all correlated with agricultural land use in the Phong Dien district, Thua Thien Hue province.

\section{Table 6. Analysis of the correlation between the factors of climate change impacts with agricultural land use}

\begin{tabular}{|c|c|c|c|c|c|c|}
\hline & & ALU & Temperature & Rainfall & Wind \& cold air & $\begin{array}{l}\text { Other extreme } \\
\text { weather }\end{array}$ \\
\hline \multirow{3}{*}{$\begin{array}{l}\text { Agricultural land } \\
\text { use (ALU) }\end{array}$} & Pearson Correlation & 1 & $0.429 * *$ & $0.215^{* \star}$ & $0.136^{*}$ & $0.469 * \star$ \\
\hline & Sig. (2-tailed) & & 0 & 0.001 & 0.041 & 0 \\
\hline & $\mathrm{N}$ & 225 & 225 & 225 & 225 & 225 \\
\hline \multirow{3}{*}{ Temperature } & Pearson Correlation & $0.429 * \star$ & 1 & 0.007 & -0.006 & $0.225^{\star \star}$ \\
\hline & Sig. (2-tailed) & 0 & & 0.922 & 0.931 & 0.001 \\
\hline & $\mathrm{N}$ & 225 & 225 & 225 & 225 & 225 \\
\hline \multirow{3}{*}{ Rainfall } & Pearson Correlation & $0.215^{\star \star}$ & 0.007 & 1 & -0.019 & 0.027 \\
\hline & Sig. (2-tailed) & 0.001 & 0.922 & & 0.777 & 0.684 \\
\hline & $\mathrm{N}$ & 225 & 225 & 225 & 225 & 225 \\
\hline \multirow{3}{*}{ Wind \& cold air } & Pearson Correlation & $0.136^{\star}$ & -0.006 & -0.019 & 1 & 0.063 \\
\hline & Sig. (2-tailed) & 0.041 & 0.931 & 0.777 & & 0.344 \\
\hline & $\mathrm{N}$ & 225 & 225 & 225 & 225 & 225 \\
\hline \multirow{3}{*}{$\begin{array}{l}\text { Other extreme } \\
\text { weather }\end{array}$} & Pearson Correlation & $0.469 * \star$ & $0.225^{* \star}$ & 0.027 & 0.063 & 1 \\
\hline & Sig. (2-tailed) & 0 & 0.001 & 0.684 & 0.344 & \\
\hline & N & 225 & 225 & 225 & 225 & 225 \\
\hline
\end{tabular}

\footnotetext{
**. Correlation is significant at the 0.01 level (2-tailed); *. Correlation is significant at the 0.05 level (2-tailed).
} 


\section{The multicollinearity phenomenon}

The VIF of the variables displayed in Table 7, are less than 10 , showing that the multicollinearity phenomenon does not affect the model. Therefore, variables are accepted for inclusion in the regression model.

\section{Table 7. Results of multicollinearity test}

\begin{tabular}{lll} 
No & Variable & VIF \\
\hline 1 & Temperature (T) & 1.225 \\
2 & Rainfall (RF) & 1.048 \\
3 & Wind and cold air (W\&C) & 1.019 \\
4 & Other extreme weather (OEW) & 1.282 \\
\hline
\end{tabular}

The results of running the regression model to determine the parameters of the variables

A regression analysis was performed step by step according to the Enter method. The model run shows that the value of $-2 \mathrm{LL}=93,124$ is not enormous, proving that the overall model has a good fit. The values of the variables in the equation are shown in Table 8.

Table 8. Variables in the Equation

\begin{tabular}{|c|c|c|c|c|c|c|c|c|c|}
\hline & & \multirow{2}{*}{ B } & \multirow{2}{*}{ S.E. } & \multirow{2}{*}{ Wald } & \multirow{2}{*}{$d f$} & \multirow{2}{*}{ Sig. } & \multirow{2}{*}{$\operatorname{Exp}(B)$} & \multicolumn{2}{|c|}{ 95\% C.I. for $\operatorname{EXP(B)}$} \\
\hline & & & & & & & & Lower & Upper \\
\hline \multirow{5}{*}{ Step 1a } & $\mathrm{T}$ & 2.964 & 0.610 & 23.572 & 1 & 0 & 19.367 & 5.854 & 64.069 \\
\hline & $\mathrm{RF}$ & 2.283 & 0.618 & 13.651 & 1 & 0 & 9.802 & 2.92 & 32.898 \\
\hline & $W \& C$ & 1.591 & 0.587 & 7.359 & 1 & 0.007 & 4.91 & 1.555 & 15.5 \\
\hline & EW & 3.139 & 0.616 & 25.953 & 1 & 0 & 23.085 & 6.899 & 77.239 \\
\hline & Constant (B0) & -3.906 & 0.891 & 19.221 & 1 & 0 & 0.02 & & \\
\hline
\end{tabular}

$\alpha=0.05 ;-2 \mathrm{LL}=93.124 \mathrm{a}$

The Sig value of all variables is $<0.05$, all independent variables influencing agricultural land use in the period 2015 2019, and have a regression relationship. With the coefficient $\mathrm{B}$ determined, the regression equation takes the form:

$\log _{e}\left(\frac{P_{i}}{1-P_{i}}\right)=-3,906+2,964 \times T+2,283 \times R F+1,591 \times W \& C+$ $3,139 \times \mathrm{OEW}$

The equation can interpret the meaning of the independent variables as follows: when the temperature variable increases so do the rainfall, the wind and the cold; when other extreme weather events occur, the impacts on agricultural land are potentially increased. Specifically:

- Wind and cold air are the factors that have the least impact on agricultural land use; when the quantity is increased by one level, the probability of affecting land use increases only 4,910 times.

- $\quad$ The precipitation factor has an average impact on agricultural land; when the air is colder more than one level, the probability of affecting land use increases only 9,802 times.

- The temperature factor has a great influence on agricultural land use; when the temperature increases by one level, the probability of affecting land use increases by 19,367 times.

- Other extreme weather affects agricultural land use the most; when other extreme weather increases one level, the effect on land use increases by 23,085 times. 3.1.3. Verify calculation results

\subsubsection{Verify calculation results}

To assess the appropriateness of the regression model to explain the impact of the selected climate change factors on the use of agricultural land, a verification process was performed as follows.

\section{Based on the questionnaire}

As displayed in Table 9, rows represent the actual number of observations and columns represent the predicted number, more detailed:

- 19 out of 31 households that are not affected are correctly predicted; the correct rate is $61.3 \%$.

- 186 out of 194 affected households are correctly predicted; the correct rate is $95.9 \%$.

- $\quad$ Thus, the average rate of correct prediction of the model is $91.1 \%$.

\section{According to analysis from calculation results}

Regarding the impact of temperature and rainfall on agricultural land use, for many years, the planning of agricultural land use in the Phong Dien district has been dependent according climatic conditions, mainly by heat, and local average annual rainfall. But the research results show that changes on temperature and precipitation affecting the 
use of agricultural land are relatively large, especially on the arrangement of different types of land use. On the other hand, temperature and rainfall variations significantly impact crop structure and the production season. Analysis of the Phong Dien climate data show that, during the period 2010-2019, the average temperature has increased in a rage of 0.8 - 2 OC, affecting the use of agricultural land about six times. Thus, the effect of temperature on agricultural land use is relatively large. Rainfall has a decreasing tendency; however, some unusually heavy rain events have occurred in a short time and for some years. Therefore, in general, rainfall has little effect on agricultural land use but only on the planting and harvesting seasons.

Table 9. Classification of factors of climate change affecting agricultural land use according to questionnaires and regression calculations

\begin{tabular}{|c|c|c|c|c|}
\hline \multirow[t]{2}{*}{ Criteria } & & \multicolumn{2}{|c|}{$\begin{array}{l}\text { Impacts on agricultural land use } \\
\text { according to the calculation }\end{array}$} & \multirow[t]{2}{*}{ Correct prediction rate $\%$} \\
\hline & & Yes & No & \\
\hline \multirow{2}{*}{$\begin{array}{l}\text { Impacts on agricultural land use } \\
\text { according to the questionnaire }\end{array}$} & Yes & 19 & 12 & 61.3 \\
\hline & No & 8 & 186 & 95.9 \\
\hline Overall percentage & & & & 91.1 \\
\hline
\end{tabular}

\section{The effects of wind, cold air on agricultural land use}

The area is controlled by two main monsoons, winter monsoon (from September to April) and summer monsoon. The coming northeast monsoon often brings cold climate and a bad weather causing rain. Often, during this period, there are coordinated effects, especially at the beginning of the season (September, October and November); there may be a northeast monsoon and a tropical low pressure with storms in many cases or other factors causing heavy rains and severe floods. Nevertheless, for many years, until February or March, there have been strong northeast monsoons, very low temperatures and little sunlight, causing great harm to crops.

Summer monsoons usually start from March or April and late until September. The southwestern wind, brings hot and humid air from the sea. The air becomes dry and hot on the Eastside, making the summer hotter, usually ranging from 36 to $37^{\circ} \mathrm{C}$ and sometimes up to 39 or $40^{\circ} \mathrm{C}$. The Phong Dien area is close to Quang Tri, where the "Laos wind" has a very strong impact. Influence of the "Laos wind", or the southwest monsoon, may be stronger than the southern districts and the Hue city, especially in the prevailing time. At this point, the southwest winds are also denser and last throughout the day, sometimes into the night.

The above shows that the wind and rainfall affecting agricultural land use in the district is moderate. Droughts in the Thua Thien Hue province have taken place quite strongly. Droughts make the land arid, the water shortage of crops is serious, leading to many cultivated areas' death or loss. This fact has also been encountered in some places in Phong My, Phong Xuan, Phong Hoa, and Phong Thu. Climate change causes prolonged hot weather conditions and droughts. Low water levels in rivers have created conditions for saltwater intrusion, penetrating inland and directly affecting agricultural production areas, especially those for wet rice cultivation.
Flooding causes many cultivated lands to be lost, leading to significant agricultural land fluctuations in recent years. In addition, storms, landslides, and tornadoes occur with relatively high intensity and frequency, also affecting agricultural lands. From the practice it can be observed that other extreme weather conditions are important influencing factors in agricultural land use. Referring to the logistic calculation results, when the other severe weather parameter changes one level, the probability of affecting agricultural land use will increase by 23,085 times.

To face climate change, the Phong Dien district government and the people must prepare to respond and adapt to drastic weather changes and sea-level rising to ensure a sustainable development. Therefore, making "Adjustment of land use planning to 2030 and the first-year land use plan of Phong Dien district" is part of the actions to respond to climate change and sea-level rise. It is necessary to equip multiple management levels, local authorities and land users as well with scientific basis for the effective management and use of land resources. They are building-specific solutions to limit the damage caused by climate change and to ensure the goal of sustainable development.

\subsubsection{Impact factors of climate change on local people's lives in Phong Dien district}

Over the past years, climate change has affected all aspects of local people's lives in the Phong Dien district, especially in agricultural production activities. Other adverse effects are related to crop structure, cultivation and animal breading, fishing and aquaculture and the risk of new diseases appearing on plants, animals, etc. These are also the impacts of climate change on specific socio-economic locality activities in the past and the years to come (Vietnam Hydrometeorology Data Center, 2020). In particular, the biggest influence is agricultural production activities. Therefore, the organization of agricultural production is an urgent issue; it should be oriented with a scientific base to be arranged and adapted to climate change according to the 
goal of sustainable development. Nevertheless, this activity has still many problems in dealing with climate change. There are no solutions nor adaptive models to help for an effective respond to climate change and people's lives still facing many difficulties. This requires the form of a territorial organization of agricultural production and solutions to mitigate climate change impacts, promoting socio-economic development and improving the life quality.
Results of a household survey carried out in 3 regions, were statistically analyzed utilizing the SPSS software. Results from the survey are shown in Table 10. They illustrate that the impact factors of climate change on life are relatively large. Climate change damages and reduces the quality of work with $80 \%$ of the votes being affected; this is a critical number for infrastructure concentrated in mountainous and delta areas.

\section{Table 10. Impacts of climate change on the local people's lives in Phong Dien district}

\begin{tabular}{|c|c|c|c|c|c|c|c|c|c|}
\hline \multirow{3}{*}{ Criteria } & \multirow{3}{*}{ Affect } & \multicolumn{8}{|l|}{ Area } \\
\hline & & \multicolumn{2}{|c|}{ Mountainous } & \multicolumn{2}{|l|}{ Delta } & \multicolumn{2}{|l|}{ Coastal } & \multicolumn{2}{|l|}{ Sum } \\
\hline & & Selection & Rate (\%) & Selection & Rate (\%) & Selection & Rate (\%) & Selection & Rate (\%) \\
\hline \multirow{2}{*}{$\begin{array}{l}\text { Damaging, reducing } \\
\text { construction quality }\end{array}$} & Yes & 3 & 1.3 & 8 & 3.6 & 34 & 15.1 & 45 & 20.0 \\
\hline & No & 49 & 21.8 & 51 & 22.7 & 80 & 35.6 & 180 & 80.0 \\
\hline \multirow{2}{*}{$\begin{array}{l}\text { Overloading the wa- } \\
\text { ter supply and drain- } \\
\text { age system }\end{array}$} & Yes & 40 & 17.8 & 30 & 13.3 & 83 & 36.9 & 153 & 68.0 \\
\hline & No & 12 & 5.3 & 29 & 12.9 & 31 & 13.8 & 72 & 32.0 \\
\hline \multirow{2}{*}{$\begin{array}{l}\text { Eroding, damaging } \\
\text { roads, canals, dikes, } \\
\text { dams... }\end{array}$} & Yes & 22 & 9.8 & 5 & 2.2 & 28 & 12.4 & 55 & 24.4 \\
\hline & No & 30 & 13.3 & 54 & 24.0 & 86 & 38.2 & 170 & 75.6 \\
\hline \multirow{2}{*}{ Other effects } & Yes & 25 & 11.1 & 17 & 7.6 & 36 & 16.0 & 78 & 34.7 \\
\hline & No & 27 & 12.0 & 42 & 18.7 & 78 & 34.7 & 147 & 65.3 \\
\hline
\end{tabular}

Climate change also overloads the water supply and drainage system; with $32 \%$ of the votes being affected, this number is small because the majority of the district already has a dyke system and has been investments for the drainage system. People's life has been somewhat improved during the period of climate change adaptation. Climate change causes landslides, damages roads, canals, dikes, and embankments. Results also indicate that $75.6 \%$ of the interviewed people agree that climate change affects people's production. Factors such as weather fluctuations, storms and floods, with increasing density and frequency, have caused these phenomena.

Furthermore, the lack of responsibility in the construction process and the subjectivity of the people regarding climate change also affects their lives and production. Also, $65.3 \%$ of people choose other effects of climate change on their lives including epidemics, environmental pollution, human health, etc.

\subsection{Proposed solutions}

- Irrigation systems are most affected by climate change. Therefore, it is necessary to complete and build a system of in-field canals; also, to improve pumping stations in order to ensure irrigation, especially during the dry season.

- Further research and research regarding new varieties of plants and animals with a good adaptability to weather conditions, short production time, high productivity and quality, and hand them over to farmers.
- To build a system of dikes and embankments to minimize floods, waterlogging and landslides along the sides of the $O$ Lau and Bo rivers. Handling riverbank erosion, especially for riverside and coastal communes, can psychologically create a comfort for people in order to live and develop socio-economically.

- Information on natural disasters, storms, floods, droughts, etc. should be communicated to the people as soon as possible through radio and television. This is an important measure to help farmers to deal with climate change events, especially storms and floods.

- Policies for lending, capital support, concessional loans, financing, re-lending, and mortgage assets need to be supported and more widely disseminated to households.

- To develop and promulgate mechanisms and policies encouraging the development of clean production models and environmentally friendly technologies for agricultural production; this can reduce emissions causing environmental pollution.

- Raising awareness about climate change and implementing natural disaster prevention plans by training courses and disseminating knowledge about climate change.

- Professional training to popularize knowledge on cultivation, farming and offshore fishing.

- By changing the planting season schedule to minimize losses due to natural disasters. A proper irrigation to ensure water for production and living during 
prolonged high temperature conditions leading to drought.

- Raising awareness of people in preventing and coping with unusual weather conditions to actively response in all circumstances.

\section{Conclusions}

This study has established a regression equation for climate change factors affecting agricultural land use. The factors highly affecting agriculture are extreme weather events and temperature. However, rainfall, wind, and cold air also affect agricultural land use in the study area. Combined with the general practice results, the accuracy of this model is up to $91.1 \%$. Moreover, the above factors affect people's lives, especially by overloading the water supply and drainage system. This topic has proposed solutions to improve the local capacity to adapt to climate change impacts on agricultural land use for both infrastructure and policies.

\section{References}

[1] Communist Party of Vietnam, online newspaper (2018). Rain and floods cause a lot of damage in Thua Thien Hue. Retrieved April 02, 2020 from https://dangcongsan.vn/xa-hoi/mua-lu-gay-nhieuthiet-hai-tai-thua-thien-hue-507619.html.
[2] Dang Thi Be Tho (2013). Impacts of climate change on agricultural production in Ben Tre province, Master's thesis in geography, Ho Chi Minh city University of Education, Vietnam.

[3] Department of Natural Resources and Environment of Phong Dien district (2020). Explanatory report on land use planning adjustment.

[4] Gujarati, D. (2004). Basic Econometrics, 4th edition, MacMillan, New York

[5] Hair, Jr.J.F Anderson, R.E, Tatham, RL \& Black, WC (1998). Multivariate Data Analysis, Prentical-Hall International, Inc.

[6] Nguyen Minh Hieu (2009). Lectures on scientific research methodology, Hue University of Agricultural and Forestry.

[7] Phong Dien District Statistical Office (2018). Statistical Yearbook Phong Dien district, Thua Thien Hue province.

[8] Vietnam Financial Magazine (2019). Climate change and 5 threats to Vietnamese agriculture. Retrieved April 02, 2020 from http://tapchitaichinh.vn/tai-chinhkinh-doanh/bien-doi-khi-hau-va-5-nguy-co-doi-voinong-nghiep-viet-nam-314416.html.

[9] Vietnam Hydrometeorology Data Center (2020). Information on meteorology, hydrology, environment and climate change. Retrieved April 02, 2020 from http://cmh.com.vn/article. 